Article

\title{
Land-Use Conflict in the Gran Chaco: Finding Common Ground through Use of the Q Method
}

\author{
Elena Zepharovich ${ }^{1,2, * \mathbb{C}}$, Michele Graziano Ceddia ${ }^{1} \mathbb{C}$ and Stephan Rist ${ }^{1,2}$ \\ 1 Centre for Development and Environment, University of Bern, 3012 Bern, Switzerland; \\ graziano.ceddia@cde.unibe.ch (M.G.C.); stephan.rist@cde.unibe.ch (S.R.) \\ 2 Institute of Geography, University of Bern, 3012 Bern, Switzerland \\ * Correspondence: elena.zepharovich@cde.unibe.ch or e.zepharovich@gmail.com
}

Received: 1 July 2020; Accepted: 17 September 2020; Published: 21 September 2020

\begin{abstract}
In a world characterized by ongoing overexploitation of finite resources-such as land and forests-stakeholder conflicts over use of remaining resources occur frequently and are likely to intensify. There is increasing awareness of the need to better understand individual stakeholders' perspectives, which often condition behavior, in order to address conflicts and inform wider policymaking. We used the $\mathrm{Q}$ method to capture the perspectives of diverse stakeholders and highlight consensus and distinguishing statements. Our results bring to the fore three main perspectives on deforestation (development, family agriculture, and subsistence) and several points of agreement and disagreement. The strongest disagreement concerns the benefits and costs of deforestation: the development perspective portrays benefits as mutual and costs as marginal, whereas the family agriculture and subsistence perspectives associate no benefits and extreme costs with deforestation-including loss of livelihoods and culture. Nevertheless, stakeholder consensus emerges on other points-especially the need for participatory long-term strategies of land use. This paper shows how the $Q$ method can be applied to better understand land-use conflicts.
\end{abstract}

Keywords: land-use conflict; Gran Chaco; Q method; perceptions; deforestation

\section{Introduction}

In a world where natural resources are finite and overexploitation is widespread, many social conflicts are driven by diverging perceptions regarding the best use of remaining resources [1]. This is particularly true in the case of the Gran Chaco, Latin America's second-largest forest after the Amazon [2].

Located in the northwest of Argentina, the Chaco Salteño (i.e., that portion of the Gran Chaco located in the province of Salta) is a particularly valuable site for studying tensions over resource use. First, Salta exhibits one of the highest deforestation rates worldwide [3,4]. Second, the province is characterized by the presence of various important stakeholder groups, including small-scale farmers, indigenous peoples, large-scale agricultural producers, civil-society actors, and government authorities-whose perceptions of land-use change and land tenure tend to diverge strongly [5-8]. Third, the legal framework surrounding land use in Argentina has been subject to considerable scrutiny-the implementation of the so-called "forest law" of 2009, in particular, has been strongly criticized [9-12]. Based on the forest law, an updated land-use map presented in 2016 indicated that over half of the deforestation in Salta was illegal [13].

Taken together, the high rates of deforestation and corresponding latent social conflicts point to the need for more nuanced approaches to governance of land and resource use in the region. One possible 
approach that has gained increasing attention in recent decades is that of incorporating stakeholder perceptions into planning of land and forest use [14]. Research shows that stakeholder perceptions of problems typically condition behavior and reveal essential insights for policymakers [15-17]. Moreover, disregard of stakeholders' perceptions and needs engenders resistance and conflict [18].

Against this background, the present study applies the $Q$ method-a mixed-method research approach-in order to identify main perceptions, areas of consensus, and distinguishing statements among land-use stakeholders in Argentina's Salta province. Our study pursued two main objectives: (i) to understand people's perspectives on deforestation and associated conflicts in the Chaco Salteño; (ii) to identify crucial points of agreement and disagreement in order to improve the current policy situation.

Highlights:

- Capturing perceptions of deforestation in the Gran Chaco using the Q method

- Understanding land-use conflicts based on consensus and distinguishing statements

- Three distinct perspectives on deforestation emerge

- There is strong polarization about who benefits or is affected by deforestation

- There is consensus about unequal participation to the land-use regulation process

\section{Methods}

\subsection{Study Area}

Our study area is located in the heart of the Gran Chaco (Figure 1), which encompasses over 1.3 million square kilometers [19] and hosts one of the largest remaining areas of uncultivated fertile soils worldwide [20]. The Gran Chaco is threatened by land-use change, in particular, expansion of agriculture [21]. Technological innovations-including new soybeans and maize hybrids-have made it possible to farm in most parts of the Gran Chaco [22]. This, in turn, has fueled rapid deforestation. Between 1977 and 2010, the Argentinean Gran Chaco lost around 6 million hectares of forest [23]. This loss of forest area has had severe environmental impacts, such as land salinization [22], reduced carbon storage [24], stronger winds, and increases in dust [25].

Moreover, expansion of the agricultural frontier affects local populations, especially their land tenure claims. In our study area, the province of Salta with a total population of 1,214,441 people [26], various stakeholder groups are arrayed in competition over land rights. First, there are local indigenous peoples (approx. 79,204 people according to the census from 2010 [26]) whose rights to territory, culture, and resources are officially anchored in Argentina's constitution as well as international agreements such as the 1969 International Labour Organisation Convention [10,27]. In practice, however, their rights have been neglected to date, as documented, for example, in a recent United Nations(UN) report on human rights [28]. Their traditional lifestyle is based on hunting, gathering, and fishing, as well as woodworks [29]. In this way, they depend strongly on the forest for their livelihoods [30], and deforestation poses a serious threat to their traditional lifestyle.

Second, the Chaco Salteño is populated by small-scale farmers called criollos, who are part of the rural population of Salta, estimated at 156,490 in the latest census from 2010 [26]. They are descendants of Europeans, who settled in the area about a century ago, and of indigenous people. Their right to land is that of "usucapio" - protected possession of land. If they can prove that they have occupied a particular area of land for over 25 years, they are eligible to claim official land titles. Nevertheless, due to various bureaucratic obstacles and a lack of resources, most such small-scale farmers in the region do not hold legal land titles. They typically engage in subsistence agriculture and extensive cattle ranching. Approximately $80 \%$ of them work in precarious conditions [31]. With less land available, the pressure on existing farmland increases, causing land degradation and conflicts within and between stakeholder groups. 


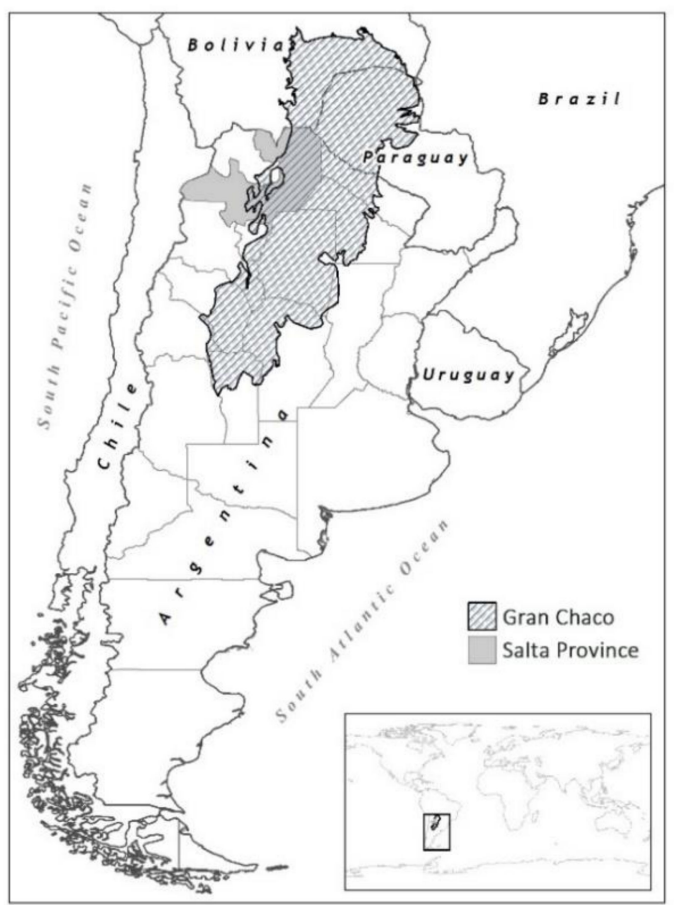

Figure 1. Map of the Gran Chaco and of the province of Salta. (Created by Matthias Fries, Centre for Development and Environment, CDE, University of Bern). The Chaco Salteño represents that part of Gran Chaco situated within the province of Salta.

Third, the area features large-scale agricultural producers who buy land from the government or other private owners and mainly use it to cultivate soya and/or for intensive cattle ranching. Their right to land is overwhelmingly recognized in the form of official private property rights. The Salta province is known for its powerful elite class of agricultural producers, who are well organized in lobbying groups with names like ProGrano, FederSal, and AgroNoa [11].

Fourth, government authorities are another key local stakeholder group, which plays a crucial role in related conflicts over land use. On the one hand, the provincial government is charged with upholding environmental laws_-such as the forest law-as well as the rights of indigenous people and small-scale farmers. On the other hand, they seek to encourage economic development by facilitating the expansion of agriculture.

Fifth and finally, civil-society actors such as environmental non-government organizations (NGOs), church groups, community organizations, and researchers participate and shape local debates around land use. Groups like Greenpeace lobby against further deforestation and push for stronger environmental protection.

These five actor groups are heterogeneous, internally differentiated, and have fluid borders [7]. All of the actors they encompass have important stakes in local land use and competition over remaining resources. Overall, the extractive agricultural system pursued by large-scale producers has increasingly impacted the distribution of benefits and exacerbated inequality between local actors [32]. At least one recent study suggests that local conservation policies would benefit strongly from greater understanding and incorporation of the perceptions and beliefs of indigenous people and small-scale farmers [33]. The present study seeks to address this knowledge/policy gap by applying the $\mathrm{Q}$ method.

\subsection{Q Methodology}

The $Q$ method helps to capture and categorize people's subjective understandings of specific topics [34]. An individual sorting exercise and factor analysis serve to group together various subjective understandings [35]. The results shed light on different points of view, as well as conflict and consensus between groups. 
Q studies are usually conducted in four steps. First, a 'concourse' is generated, comprising the universe of statements describing the topic at hand (e.g., deforestation). The statements building the concourse are derived by the researcher from interviews, newspapers, literature, and other information sources concerned with the topic. Second, the most relevant statements are selected by the researcher, balancing coverage (inclusion of all relevant aspects) and avoiding overlap (not repeating aspects). Third, the statements are sorted by informed individuals on a grid according to their preferences. This process is usually followed by a post-sorting interview. Finally, a factor analysis is conducted to identify the 'factors.' A 'factor' is one of the various key viewpoints on the topic.

We chose the $\mathrm{Q}$ method for several reasons. Addams and Proops [36] have referred to it as an almost perfect technique for initial stages of environmental policy analysis, because it enables identification of public perceptions of key issues. Of particular importance to our research, it also enables identification of marginalized perspectives like those of the indigenous people and small-scale farmers in our study area [37,38]. Further, the $Q$ method is particularly suited to conservation problems [39] in which stakeholder positions tend not to be neatly dichotomous-i.e., conserve versus exploit—but somewhere in the middle. It has been used in various contexts; for example, to explore the socioecological vulnerability of indigenous peoples in the US [40], understanding conservation conflicts in Brazil [41] as well as to incorporate stakeholder views in forest planning [14,42-44]. In the context of deforestation, $\mathrm{Q}$ has been applied to investigate opinions on REDD+ $[45,46]$.

Nevertheless, it is important to keep in mind that $Q$ aims at revealing existing perceptions on a given topic, rather than an objective "truth," but does not necessarily indicate how those perceptions are distributed across the whole population $[35,47]$. Overall, the method ideally matches our study aims, as revealing people's attitudes regarding local resource use and overexploitation is critical to problem solution, both normatively and politically.

\subsection{Implementing the $Q$ Study}

For this Q study, we first conducted 25 semi-structured interviews with informed individuals from all five stakeholder groups between July and August 2017. The interviewees comprised civil-society actors $(n=7)$; government representatives from different departments and ministries, including authorities responsible for agriculture, sustainability, indigenous peoples, national or provincial agencies, etc. (11); indigenous actors themselves (3); small-scale farmers (2); and large-scale producers (2). All interviews were conducted in Spanish. To select the interviewees, we first approached official institutions and then continued with snowball sampling. We recorded and transcribed the interviews in order to identify and extract statements for the $Q$ study. To account for the imbalance in interviews between the stakeholders, additional statements were derived from field notes from meetings with indigenous actors, small-scale farmers and large-scale producers. A total of 36 statements were selected which are presented in Table 1 . Next, we shortened and simplified the statements to make the sorting process easier for participants. Then, a second series of fieldwork was carried out between April and May 2018 to implement the Q study. In this second fieldwork, five people per stakeholder group were tasked with sorting the statements-on cards-along a grid, ranging from -5 (total disagreement) to +5 (complete agreement). The main selection criteria for the participants was for them to have a strong opinion on deforestation. After sorting of the cards, the participants were asked to explain their rationale for sorting the cards in a particular way. Finally, we analysed the data with PQMethod [48]. The software provides two options for performing the factor analysis: principal component analysis (PCA) or centroid factor analysis. A detailed comparison between the two approaches can be found in Kline [49]. We opted for a PCA [35,50], with varimax rotation, as our study aims at understanding an issue [51]. The results of the PCA are the factors, presented in the following section. 
Table 1. List of statements with $Q$ sort values $(Q)$ and $z$-scores $(z)$. $Q$ values indicate the degree of agreement with the statement; for example, a value of 4 represents strong agreement with the statement, and a value of -4 represents strong disagreement. The z-score indicates how far a statement lies from the middle of the distribution, based on a standardized mean and standard deviation.

\begin{tabular}{|c|c|c|c|c|c|c|c|}
\hline \multirow[t]{2}{*}{ No. } & \multirow[t]{2}{*}{ Statement } & \multicolumn{2}{|c|}{ Factor 1} & \multicolumn{2}{|c|}{ Factor 2} & \multicolumn{2}{|c|}{ Factor 3} \\
\hline & & $Q$ & $\mathbf{z}$ & $Q$ & $\mathbf{z}$ & $Q$ & $\mathbf{z}$ \\
\hline 1 & $\begin{array}{l}\text { The government designs policies without } \\
\text { considering real conditions and needs. }\end{array}$ & 5 & 1.332 & 2 & 0.981 & 2 & 0.62 \\
\hline 2 & $\begin{array}{l}\text { Many politicians own land and pursue their } \\
\text { own interests. }\end{array}$ & 2 & 1.018 & 0 & 0.239 & 3 & 1.144 \\
\hline 3 & $\begin{array}{l}\text { Clearly, large-scale producers have much } \\
\text { better access and more opportunities to } \\
\text { present their problems to the authorities. }\end{array}$ & 3 & 1.062 & 2 & 0.725 & 1 & 0.465 \\
\hline 4 & $\begin{array}{l}\text { Small-scale farmers are excluded from } \\
\text { decisions about deforestation. }\end{array}$ & 2 & 0.837 & 0 & 0.023 & -2 & -0.124 \\
\hline 5 & $\begin{array}{l}\text { The guarantee of a prior, free, and informed } \\
\text { consultancy about deforestation } \\
\text { is neglected. }\end{array}$ & 1 & 0.765 & -1 & -0.44 & 0 & 0.245 \\
\hline 6 & $\begin{array}{l}\text { Large-scale producers are excluded from } \\
\text { decisions about deforestation. }\end{array}$ & -4 & -663 & -2 & -0.77 & -3 & -0.264 \\
\hline 7 & $\begin{array}{l}\text { Indigenous people are excluded from } \\
\text { decisions about deforestation. }\end{array}$ & 0 & 0.334 & 0 & -0.07 & 4 & 1.429 \\
\hline 8 & $\begin{array}{l}\text { It is unfair that the processes for } \\
\text { deforestation permissions are fast, } \\
\text { while those for protection are slow. }\end{array}$ & 4 & 1.325 & 0 & -0.41 & 1 & 0.495 \\
\hline 9 & $\begin{array}{l}\text { Concerning land rights, the government } \\
\text { attends to all actors equally. }\end{array}$ & -5 & -905 & 1 & 0.267 & -4 & -0.779 \\
\hline 10 & $\begin{array}{l}\text { It makes me angry that there is corruption in } \\
\text { the process to get land titles. }\end{array}$ & 0 & 0.152 & 1 & 0.589 & 2 & 0.804 \\
\hline 11 & $\begin{array}{l}\text { Indigenous people are passive in the fight } \\
\text { against deforestation. }\end{array}$ & -1 & -266 & 0 & -0.09 & 0 & 0.37 \\
\hline 12 & $\begin{array}{l}\text { The laws regulating deforestation are } \\
\text { completely ignored. }\end{array}$ & 2 & 0.983 & -1 & -0.64 & -1 & -0.3 \\
\hline 13 & $\begin{array}{l}\text { The forest is a resource that needs to } \\
\text { be exploited. }\end{array}$ & -1 & -358 & 3 & 1.109 & -3 & -0.424 \\
\hline 14 & $\begin{array}{l}\text { Indigenous people are overprotected } \\
\text { concerning land rights. }\end{array}$ & -2 & -812 & 1 & 0.41 & -4 & -0.548 \\
\hline 15 & $\begin{array}{l}\text { Indigenous people only live in the forest } \\
\text { because there is no alternative. }\end{array}$ & -2 & -0.84 & 2 & 0.652 & -1 & -0.91 \\
\hline 16 & $\begin{array}{l}\text { Large-scale producers are overprotected } \\
\text { concerning land rights. }\end{array}$ & 1 & 0.77 & -2 & -0.79 & 0 & 0.3 \\
\hline 17 & $\begin{array}{l}\text { When they cut trees, it's like they cut my } \\
\text { mother because the trees provide me with } \\
\text { food and shade. }\end{array}$ & 1 & 0.768 & -3 & -1.08 & 3 & 1.258 \\
\hline 18 & $\begin{array}{l}\text { Small-scale farmers are overprotected } \\
\text { concerning land rights. }\end{array}$ & -2 & -215 & -1 & -0.43 & -1 & -0.37 \\
\hline 19 & $\begin{array}{l}\text { If there is one thing that destroys the forest, } \\
\text { it is the cows of the small-scale farmers. }\end{array}$ & -2 & -051 & 2 & 0.965 & -2 & -0.635 \\
\hline 20 & $\begin{array}{l}\text { Small-scale farmers produce in an } \\
\text { environmentally friendly way. }\end{array}$ & 3 & 1.213 & -1 & -0.67 & -3 & -0.474 \\
\hline
\end{tabular}


Table 1. Cont.

\begin{tabular}{|c|c|c|c|c|c|c|c|}
\hline \multirow[t]{2}{*}{ No. } & \multirow[t]{2}{*}{ Statement } & \multicolumn{2}{|c|}{ Factor 1} & \multicolumn{2}{|c|}{ Factor 2} & \multicolumn{2}{|c|}{ Factor 3} \\
\hline & & $\mathbf{Q}$ & $\mathbf{z}$ & $\mathbf{Q}$ & $\mathbf{z}$ & $\mathbf{Q}$ & $\mathbf{z}$ \\
\hline 21 & $\begin{array}{l}\text { Large-scale producers are the only ones who } \\
\text { deforest legally. }\end{array}$ & -3 & -352 & -2 & -0.82 & -1 & -04 \\
\hline 22 & Without trees, there is no life for us. & 2 & 0.816 & 1 & 0.633 & 3 & 1.034 \\
\hline 23 & $\begin{array}{l}\text { If I own the land, I should be allowed to use } \\
\text { it the way I want to. }\end{array}$ & -4 & -716 & -4 & -1.41 & 0 & 0.084 \\
\hline 24 & $\begin{array}{l}\text { Everybody should respect indigenous } \\
\text { people's right to land. }\end{array}$ & 0 & 0.225 & 3 & 1.212 & 5 & 1.898 \\
\hline 25 & $\begin{array}{l}\text { Small producers are affected the most by } \\
\text { deforestation because there are no laws that } \\
\text { protect them. }\end{array}$ & 4 & 1.228 & -1 & -0.46 & 1 & 0.599 \\
\hline 26 & $\begin{array}{l}\text { Indigenous people are affected the most by } \\
\text { deforestation because they are strongly } \\
\text { connected to nature. }\end{array}$ & 1 & 0.718 & 1 & 0.636 & 4 & 1.368 \\
\hline 27 & We lack the money to stop deforestation. & 0 & -151 & 0 & -0.08 & -1 & -0.175 \\
\hline 28 & $\begin{array}{l}\text { Land-use change helps everybody because } \\
\text { it contributes to development. }\end{array}$ & -1 & -0.601 & 5 & 2.002 & -2 & -1.13 \\
\hline 29 & $\begin{array}{l}\text { In my opinion, only the large-scale } \\
\text { producers benefit from deforestation. }\end{array}$ & 3 & 1.133 & -2 & -0.78 & 2 & 0.795 \\
\hline 30 & $\begin{array}{l}\text { The national government gets all the } \\
\text { benefits from deforestation through the } \\
\text { money paid by companies. }\end{array}$ & 1 & 0.536 & -3 & -1.28 & 0 & 0.035 \\
\hline 31 & Social inequality causes deforestation. & -1 & -0.239 & -5 & -2.01 & 0 & 0.16 \\
\hline 32 & Where there is forest, there is poverty. & -3 & -1.449 & 3 & 1.277 & -5 & -1.878 \\
\hline 33 & Lack of education causes people to cut trees. & -1 & -0.319 & -3 & -0.83 & 1 & 0.439 \\
\hline 34 & Deforestation creates employment. & -3 & -1.407 & 4 & 1.624 & -2 & -1.213 \\
\hline 35 & $\begin{array}{l}\text { There is a lack of job opportunities for } \\
\text { indigenous people. }\end{array}$ & 0 & 0.138 & 4 & 1.595 & 2 & 0.67 \\
\hline 36 & $\begin{array}{l}\text { We are dying because of the pesticides that } \\
\text { they put on the fields. }\end{array}$ & 0 & -0.009 & -4 & -1.88 & 1 & 0.594 \\
\hline
\end{tabular}

\section{Results}

Based on the factor analysis, we identified three factors, that is, three different main perceptions of deforestation, as presented in the following section. A table with a complete list of statements including values and z-scores is presented below (see Table 1), followed by another table with the exact factor loadings of each participant (see Table 2). After discussing the factors, we present the distinguishing statements and the consensus statements.

\subsection{Factors}

\subsubsection{Factor 1: 'Family Agriculture'}

Five small-scale farmers and two civil-society actors were significantly associated with this factor. According to this point of view, the most important problem is the lack of participation in land-use decisions and the lack of political will to distribute land titles. Participants claimed this is due to the government being very closely aligned with the interests of large-scale producers in regard to exploitation of forest resources. The actors sharing this perspective feel that deforestation by large-scale producers threatens the livelihoods of rural populations by displacing small-scale 
farmers and indigenous people. This viewpoint also suggests that indigenous people and small-scale farmers do not strive for profit maximization, but rather for quality of life and preservation of their current lifestyle.

Table 2. Factor loadings. Bold script denotes significant loadings. In the actor IDs, $\mathrm{P}$ stands for large-scale producer, $\mathrm{G}$ for governmental actor, $\mathrm{N}$ for civil-society actor, $\mathrm{C}$ for small-scale farmer, and I for indigenous person.

\begin{tabular}{ccccc}
\hline Sorts & Actor & Factor $\mathbf{1}$ & Factor $\mathbf{2}$ & Factor 3 \\
\hline 1 & P1 & -0.2537 & $\mathbf{0 . 7 4 7 8}$ & -0.0481 \\
2 & $\mathrm{P} 2$ & -0.0333 & $\mathbf{0 . 6 7 8 1}$ & -0.4320 \\
3 & $\mathrm{P} 3$ & -0.2397 & $\mathbf{0 . 6 6 4 3}$ & -0.0698 \\
4 & $\mathrm{P} 4$ & -0.0237 & $\mathbf{0 . 6 8 4 2}$ & 0.1145 \\
5 & $\mathrm{P} 5$ & 0.2100 & $\mathbf{0 . 6 6 3 0}$ & 0.1074 \\
6 & $\mathrm{G} 1$ & 0.5408 & 0.2514 & 0.5781 \\
7 & $\mathrm{G} 2$ & 0.0136 & $\mathbf{0 . 6 0 5 9}$ & 0.1310 \\
8 & $\mathrm{G} 3$ & -0.0745 & $\mathbf{0 . 7 6 7 1}$ & -0.1846 \\
9 & $\mathrm{G} 4$ & 0.1206 & 0.3826 & 0.0680 \\
10 & $\mathrm{G} 5$ & 0.6479 & 0.2026 & 0.5898 \\
11 & $\mathrm{~N} 1$ & 0.5634 & 0.0865 & 0.5733 \\
12 & $\mathrm{~N} 2$ & 0.6681 & 0.0671 & 0.5738 \\
13 & $\mathrm{~N} 3$ & $\mathbf{0 . 5 6 0 6}$ & 0.1676 & 0.4058 \\
14 & $\mathrm{~N} 4$ & 0.4561 & $\mathbf{0 . 5 2 8 3}$ & -0.2021 \\
15 & $\mathrm{~N} 5$ & $\mathbf{0 . 7 5 8 8}$ & 0.0591 & 0.2778 \\
16 & $\mathrm{C} 1$ & $\mathbf{0 . 8 5 2 8}$ & -0.1178 & 0.0877 \\
17 & $\mathrm{C} 2$ & $\mathbf{0 . 6 2 7 7}$ & -0.0842 & 0.3407 \\
18 & $\mathrm{C} 3$ & $\mathbf{0 . 7 4 7 0}$ & -0.1658 & 0.2266 \\
19 & $\mathrm{C} 4$ & $\mathbf{0 . 7 7 2 0}$ & 0.0496 & 0.1145 \\
20 & $\mathrm{C} 5$ & $\mathbf{0 . 6 9 6 6}$ & -0.0524 & 0.2897 \\
21 & $\mathrm{I} 1$ & 0.1571 & -0.1653 & $\mathbf{0 . 7 3 8 9}$ \\
22 & $\mathrm{I} 2$ & 0.2374 & 0.0128 & $\mathbf{0 . 7 8 4 4}$ \\
23 & $\mathrm{I} 3$ & 0.4505 & -0.0277 & $\mathbf{0 . 7 6 7 3}$ \\
24 & $\mathrm{I} 4$ & 0.5305 & 0.0196 & 0.5243 \\
25 & $\mathrm{I} 5$ & 0.4535 & -0.1244 & 0.3749 \\
\hline & & & & \\
\hline
\end{tabular}

\subsubsection{Factor 2: 'Development'}

Five large-scale agricultural producers, two governmental actors, and one civil-society actor were associated with this factor. According to this point of view, deforestation is not a problem, but rather the solution. Participants sharing this perspective believe that land-use change contributes to development and creates work. While some such actors acknowledge possible negative side effects, they see no alternative to forest exploitation. They stated that if the government fails to manage the forest efficiently, the cows of the small-scale farmers would degrade the forest completely and indigenous people would persist in poverty. According to this perspective, the province of Salta must develop, and this is facilitated by deforestation or land-use change.

\subsubsection{Factor 3: 'Subsistence'}

Three indigenous participants were significantly associated with this factor. The findings suggest that indigenous people feel excluded and discriminated against by the government. They feel as though they suffer the worst consequences of deforestation, as they can no longer find sufficient food or medicinal plants. Participants voiced constant fear of being displaced and of exposure to floods and pesticides. They feel like they are not recognized in their rights to land and discriminated against because of their culture. 


\subsection{Distinguishing and Consensus Statements}

In the following, we present the results of our $Q$ study revealing which statements were sorted similarly or differently across all factors to a significant extent. Notably, the existence of a significant difference or consensus does not confirm disagreement or agreement on its own, as people may interpret the same statements in varying ways. Indeed, language-in-use rests on dynamics that Cohen's $d$ and Stephenson's standard error of differences cannot capture [52,53]. As a result, our broader analysis strongly relies on the additional information captured in our post-sorting interviews.

In order to identify areas of conflict between the actors concerning deforestation, we looked for distinguishing statements between the factor groups. Detailed tables containing the full list of distinguishing statements for each factor (Table A1 for factor 1, Table A2 for factor 2, and Table A3 for factor 3) can be found in Appendix A. Distinguishing statements are those that have been ranked significantly different by participants in one factor group in comparison with those in another factor group. The difference is considered statistically significant when $p<0.05$.

Participants associated with factor 1 and factor 3 share the same basic understanding of deforestation as something negative. However, they are distinguished by their view of whether or not small-scale farmers produce in an environmentally friendly way: factor 1 actors believe they do, while factor 3 actors contest it.

With regard to participants associated with factor 1 and factor 2, respectively, the strongest disagreement concerns the impact of deforestation on society. Participants associated with factor 2 believe that 'Where there is forest, there is poverty' and that the cattle kept by small-scale farmers, in particular, degrades the forest. For them, deforestation presents a solution, as it contributes to development and creates employment. Further, they feel that the government treats all actors equally. This is disputed by participants associated with factor 1 .

Factor 3 participants disagree with factor 2 participants over the same issues as participants associated with factor 1 . In addition, factor 3 and factor 2 participants differ in that factor 2 actors perceive indigenous people as overprotected concerning land rights. Further, factor 3 participants agreed with the statements "We are dying because of the pesticides they put on the fields" and "It feels like they cut my mother when they cut down a tree," as well as that social inequality causes deforestation. By contrast, factor 2 participants disagreed with all of these statements.

In summary, the greatest distinction between the factor groups concerns perceptions of who is affected by deforestation and who benefits from deforestation. Factor 2 participants view everyone as benefitting from deforestation, whereas factor 1 and factor 3 participants contest the positive impacts of deforestation, emphasize its negative impacts (e.g., floods, biodiversity loss), and highlight the positive impacts of preserving the forest.

Besides the considerable differences in perception between the factor groups, there was also some agreement. The consensus statements shown in Table 3 do not differ significantly between the factor groups (i.e., $p>0.01$ ). There were seven consensus statements, meaning statements that were ranked similarly in all factor groups. In general, it appears that a significant consensus among actors was found with respect to statements reflecting participation to the land-use regulation process and procedural issues (e.g., statements 1,3,10, and 27) or with respect to the condition of indigenous peoples (e.g., statements 11 and 26). 
Table 3. Consensus statements.

\begin{tabular}{|c|c|c|c|c|c|c|c|}
\hline \multirow[b]{2}{*}{ No. } & \multirow[b]{2}{*}{ Statement } & \multicolumn{2}{|c|}{ Factor 1} & \multicolumn{2}{|c|}{ Factor 2} & \multicolumn{2}{|c|}{ Factor 3} \\
\hline & & Q-Sort & Z-Score & Q-Sort & Z-Score & Q-Sort & Z-Score \\
\hline $1 * *$ & $\begin{array}{l}\text { The government designs policies without } \\
\text { considering real conditions and needs. }\end{array}$ & 5 & 1.332 & 2 & 0.981 & 2 & 0.62 \\
\hline $3 *$ & $\begin{array}{l}\text { Clearly, the large-scale producers have } \\
\text { much more access to present their problems } \\
\text { to the authorities. }\end{array}$ & 3 & 1.062 & 2 & 0.725 & 1 & 0.465 \\
\hline $10 *$ & $\begin{array}{l}\text { It makes me angry that there is corruption in } \\
\text { the process to get land titles. }\end{array}$ & 0 & 0.152 & 1 & 0.589 & 2 & 0.804 \\
\hline $11 *$ & $\begin{array}{l}\text { The indigenous people are passive in the } \\
\text { fight against deforestation. }\end{array}$ & -1 & -0.266 & 0 & -0.09 & 0 & 0.37 \\
\hline $22 *$ & Without trees, there is no life for us. & 2 & 0.816 & 1 & 0.633 & 3 & 1.034 \\
\hline $26 * *$ & $\begin{array}{l}\text { The indigenous people are the most affected } \\
\text { by deforestation because they are very } \\
\text { connected to nature. }\end{array}$ & 1 & 0.718 & 1 & 0.636 & 4 & 1.368 \\
\hline $27 *$ & We lack the money to stop deforestation. & 0 & -0.151 & 0 & -0.08 & -1 & -0.175 \\
\hline
\end{tabular}

\section{Discussion}

The present study sought to identify what distinguishes and what connects the perceptions of deforestation among various stakeholders in order to better understand current land-use conflicts. In the following section, we first discuss what separates, and second what links, the different stakeholders' perceptions concerning land-use conflicts in the Chaco Salteño.

The disagreement between actors associated with factor 1 and actors associated with factor 3 concerning whether small-scale farmers produce in an environmentally friendly way is particularly important, as it highlights the existence of a cleavage between two parties that otherwise agree on many issues. In our interviews, small-scale farmers claimed to be the only ones who truly protect the environment from illegal deforestation, as they view their communities as well organized and willing to block bulldozers, for example, even with their own bodies. They exhibit awareness that their own agricultural practices may not be sustainable in the long term, but they feel that their environmental impact is relatively small compared to large-scale producers, as has been confirmed by [54]. By contrast, indigenous actors associated with factor 3 disagree strongly with this statement for two reasons, as revealed in the interviews. First, some indigenous participants make no distinction between "small-scale" and "large-scale" farmers-to these indigenous actors, all such farmers are criollos, i.e., white farmers (term used in the Spanish statement). Second, many indigenous people feel that the cattle of the small-scale farmers cause habitat destruction and cannot be considered environmentally friendly.

In spite of such a difference, the overall results suggest that it is not simply "everyone against everyone" in these land-use conflicts, but rather that factor 1 and factor 3 actors perceive deforestation rather similarly. This is in line with the findings of Boffa [55], who argued that the conflict is not mainly between small-scale farmers and indigenous people or government. Instead, she observed that the frontline in the battle over deforestation largely cuts between a group with an economic interest in capitalistic expansion, on the one hand, and a pluri-ethnic group, on the other.

Overall, the clearest point of polarization concerns who is perceived as carrying the costs of deforestation and who is perceived as benefitting from it. The statement best exemplifying this is "Land-use change helps everybody because it contributes to development." Actors associated with factor 2 fully agree with this statement and view economic "development" as the primary goal, i.e., reduction of unemployment, construction of infrastructure, and growth of GDP. For them, the only 
way to reach this goal is through deforestation and effective forest management. This discourse, largely associated with economic elites, is widely accepted in Argentina [56]. In this vision of "modernization" and "efficiency," there is no place for small-scale farming or indigenous culture [57]. By contrast, actors associated with factor 1 and factor 3 dispute this view of development. Instead, they emphasize the importance of preserving the forest, their culture, and their current way of life, stating that they have only experienced negative aspects of deforestation, including loss of livelihood, increased floods, stronger winds, and biodiversity loss. Their perception is supported by several studies $[32,58,59]$.

Another key statement, reflecting a similar issue, is "Where there is forest, there is poverty." Participants associated with factor 2 said they see a direct relationship between living in the forest and not having access to water, electricity, education, health services, labor markets, etc.- -representing a state of complete poverty. This picture is supported by the fact that, overall, $20 \%$ of indigenous people in the region still have unsatisfied basic needs, and approximately $20 \%$ are still completely illiterate [60]. Nevertheless, stakeholders associated with factor 1 and factor 3 disagree with this statement linking forests to poverty. As evidenced by our interviews, they identify the forest with life and with the provision of fruit, shade, animals, fresh air, building materials, and more. Additionally, they express an emotional connection with the forest that is not easily reconciled with the prevailing market-based logic of individual private property [61]. Indeed, in line with [62], our results show that it is crucial to recognize the different ways that people relate to nature and to consider them in the design of environmental policies.

With respect to consensus statements, the strongest area of agreement concerns statements about participation. For example, concerning the statement "The government does not consider the real conditions and needs of the stakeholders," actors associated with factor 1 point to a lack of participation and the prevalence of top-down policies. Similarly, actors associated with factor 2 criticized what they view as short-sightedness in policy design, with most measures geared towards upcoming election cycles. Finally, actors associated with factor 3 highlighted apparent government disregard for their needs, evidenced by the government selling land to companies without considering that people live on the land. These conditions create problems for all the actors involved. In this way, there is an emerging consensus about the need for long-term policies on land tenure, designed in a bottom-up participatory manner.

Lastly, consensus was also found regarding the statement that large-scale producers have better access to authorities. However, there was disagreement about the reasons for their superior access. Actors associated with factor 2 argued that large-scale producers are simply better organized and share a common vision, whereas small-scale producers and indigenous people are much more scattered-both geographically and in terms of their visions-making it difficult to collaborate with them. On their part, actors associated with factor 1 and with factor 3 exhibited reluctance to engage with the formal legal system, because they feel that the legal system is created to protect the rich and not to bring justice, as one of the participants explained. This highlights that such actors have very little trust in local institutions. According to Boffa [63], the government wants to include indigenous people in the growing market economy to provide the workforce and to facilitate sales of land as private property. In this way, it appears essential for policymakers not only to facilitate access to the authorities, but to also build trust in them to encourage people to engage in local land-use policies.

\section{Conclusions}

In this study, we applied the $\mathrm{Q}$ method to identify diverse stakeholder perceptions of deforestation in the Chaco Salteño. Our results reveal three main perspectives that simultaneously illustrate a divide between capitalistic development perspectives (factor 2) and more conservation-focused perspectives (factor 1 and factor 3).

Nevertheless, some important common ground can be found among the various perspectives, which can be summarized according to the following two points. First, all the identified perspectives 
highlight the need for greater participation in the land-use regulation process. This is in line with the findings from other authors [11,12]. Second, there is general consensus that the government has enough resources to address the issue. Further discussion with the actors indicates that there is a united call to address existing conflicts by clarifying the conditions of land tenure once and for all. These are novel insights. This common ground should be used to build consensus on appropriate policy interventions. Clearly, there are many ways to go about it. As deforestation remains one of the most important drivers of both biodiversity loss and anthropogenic climate change, empowering local communities and recognizing their land claims [64,65], acknowledging that there is a variety of land tenure regimes beyond individual private property, could be extremely effective $[65,66]$. To this end, we would recommend offering technical support to rural communities (to enable securing and/or regularization of land titles) while also facilitating self-organization and participation in decision-making processes $[12,30,64]$. While the results of this $Q$ study cannot be generalized, our findings highlight the value and usefulness of identifying and including people's perceptions of land-use conflicts, and indicate the need for further investigation of land-use conflicts in Salta in particular.

Author Contributions: Conceptualization, E.Z., M.G.C.; method, E.Z.; software, E.Z.; formal analysis, E.Z.; writing—original draft and preparation, E.Z.; writing—review and editing, E.Z. and M.G.C.; supervision, M.G.C. and S.R.; funding acquisition, M.G.C. All authors have read and agreed to the published version of the manuscript.

Funding: This research was funded by ERC Consolidator Grant 681518-INCLUDE.

Acknowledgments: We thank the reviewers for their valuable feedback.

Conflicts of Interest: The authors declare no conflict of interest. The funders had no role in the design of the study; in the collection, analyses, or interpretation of data; in the writing of the manuscript, or in the decision to publish the results.

\section{Appendix A}

Table A1. Distinguishing Statements for Factor 1.

\begin{tabular}{|c|c|c|c|c|c|c|c|}
\hline \multirow[b]{2}{*}{ No. } & \multirow{2}{*}{$\begin{array}{l}\text { Distinguishing Statements for Factor } 1(p<0.05 \\
\left.\text { Asterisk }\left({ }^{*}\right) \text { Indicates Significance at } p<0.01\right) \\
\text { Statement }\end{array}$} & \multicolumn{2}{|c|}{ Factor 1} & \multicolumn{2}{|c|}{ Factor 2} & \multicolumn{2}{|c|}{ Factor 3} \\
\hline & & Q-SV & Z-SCR & Q-SV & Z-SCR & Q-SV & Z-SCR \\
\hline 8 & $\begin{array}{l}\text { It is unfair that the processes for deforestation } \\
\text { permissions are fast, while those for protection are slow }\end{array}$ & 4 & 1.33 & 0 & -0.41 & 1 & 0.49 \\
\hline 20 & $\begin{array}{l}\text { The criollos produce in an environmentally } \\
\text { friendly way. }\end{array}$ & 3 & $1.21 *$ & -1 & -0.67 & -3 & -1.47 \\
\hline 12 & $\begin{array}{l}\text { The laws regulating deforestation are } \\
\text { completely ignored. }\end{array}$ & 2 & $0.98 *$ & -1 & -0.64 & -1 & -0.30 \\
\hline 4 & $\begin{array}{l}\text { The criollos are excluded from decisions } \\
\text { about deforestation. }\end{array}$ & 2 & $0.84 *$ & 0 & 0.02 & -2 & -1.12 \\
\hline 24 & $\begin{array}{l}\text { Everybody should respect the indigenous people's } \\
\text { right to land. }\end{array}$ & 0 & $0.23^{*}$ & 3 & 1.21 & 5 & 1.90 \\
\hline 33 & Lack of education causes people to cut trees. & -1 & -0.32 & -3 & -0.83 & 1 & 0.44 \\
\hline 13 & The forest is a resource that needs to be exploited. & -1 & -0.36 * & 3 & 1.11 & -3 & -1.42 \\
\hline 14 & $\begin{array}{l}\text { The indigenous peoples are overprotected concerning } \\
\text { land rights. }\end{array}$ & -2 & -0.81 & 1 & 0.41 & -4 & -1.55 \\
\hline 15 & $\begin{array}{l}\text { The indigenous peoples only live in the forest because } \\
\text { there is no alternative. }\end{array}$ & -2 & -0.84 & 2 & 0.65 & -1 & -0.09 \\
\hline 18 & The criollos are overprotected concerning land rights. & -2 & -1.21 & -1 & -0.43 & -1 & -0.37 \\
\hline 21 & $\begin{array}{l}\text { The big producers are the only ones who } \\
\text { deforest legally. }\end{array}$ & -3 & -1.35 & -2 & -0.82 & -1 & -0.40 \\
\hline
\end{tabular}


Table A2. Distinguishing Statements for Factor 2.

\begin{tabular}{|c|c|c|c|c|c|c|c|}
\hline \multirow[b]{2}{*}{ No. } & \multirow{2}{*}{$\begin{array}{l}\text { Distinguishing Statements for Factor } 2(p<0.05 \\
\left.\text { Asterisk }\left(^{*}\right) \text { Indicates Significance at } p<0.01\right) \\
\text { Statement }\end{array}$} & \multicolumn{2}{|c|}{ Factor 1} & \multicolumn{2}{|c|}{ Factor 2} & \multicolumn{2}{|c|}{ Factor 3} \\
\hline & & Q-SV & Z-SCR & Q-SV & Z-SCR & Q-SV & Z-SCR \\
\hline 28 & $\begin{array}{l}\text { Land-use change helps everybody because it } \\
\text { contributes to development. }\end{array}$ & -1 & -0.60 & 5 & $2 *$ & -2 & -1.13 \\
\hline 34 & Deforestation creates employment. & -3 & -1.41 & 4 & $1.62 *$ & -2 & -1.21 \\
\hline 35 & $\begin{array}{l}\text { There is a lack of work opportunities for } \\
\text { indigenous peoples. }\end{array}$ & 0 & 0.14 & 4 & $1.59 *$ & 2 & 0.67 \\
\hline 32 & Where there is forest there is poverty. & -3 & -1.45 & 3 & $1.28 *$ & -5 & -1.88 \\
\hline 24 & $\begin{array}{l}\text { Everybody should respect the indigenous people's } \\
\text { right to land. }\end{array}$ & 0 & 0.23 & 3 & 1.21 & 5 & 1.90 \\
\hline 13 & The forest is a resource that needs to be exploited. & -1 & -0.36 & 3 & 1.11 * & -3 & -1.42 \\
\hline 19 & $\begin{array}{l}\text { If there is one thing that destroys the forest it's the } \\
\text { cows of the criollos. }\end{array}$ & -2 & -1.05 & 2 & $0.97 *$ & -2 & -0.63 \\
\hline 15 & $\begin{array}{l}\text { The indigenous peoples only live in the forest } \\
\text { because there is no alternative. }\end{array}$ & -2 & -0.84 & 2 & 0.65 & -1 & -0.09 \\
\hline 14 & $\begin{array}{l}\text { The indigenous peoples are overprotected } \\
\text { concerning land rights. }\end{array}$ & -2 & 0.81 & 1 & 0.41 * & -4 & -1.55 \\
\hline 9 & $\begin{array}{l}\text { Concerning land rights, the government attends to } \\
\text { all actors equally. }\end{array}$ & -5 & 1.91 & 1 & $0.27^{*}$ & -4 & -1.78 \\
\hline 2 & $\begin{array}{l}\text { Many politicians own land and take care of their } \\
\text { own interests. }\end{array}$ & 2 & 1.02 & 0 & $0.24 *$ & 3 & 1.14 \\
\hline 4 & $\begin{array}{l}\text { The criollos are excluded from decisions } \\
\text { about deforestation. }\end{array}$ & 2 & 0.84 & 0 & $0.02 *$ & -2 & -1.12 \\
\hline 8 & $\begin{array}{l}\text { It is unfair that the processes for deforestation } \\
\text { permissions are fast, while those for protection } \\
\text { are slow. }\end{array}$ & 4 & 1.33 & 0 & $-0.41 *$ & 1 & 0.49 \\
\hline 5 & $\begin{array}{l}\text { The guarantee of prior, free, and informed } \\
\text { consultancy about deforestation is neglected. }\end{array}$ & 1 & 0.77 & -1 & -0.44 & 0 & 0.25 \\
\hline 25 & $\begin{array}{l}\text { The small producers are the most affected by } \\
\text { deforestation, because there are no laws that } \\
\text { protect them. }\end{array}$ & 4 & 1.23 & -1 & $-0.46^{*}$ & 1 & 0.60 \\
\hline 20 & $\begin{array}{l}\text { The criollos produce in an environmentally } \\
\text { friendly way. }\end{array}$ & 3 & 1.21 & -1 & -0.67 & -3 & -1.47 \\
\hline 29 & $\begin{array}{l}\text { In my opinion, only the big producers benefit } \\
\text { from deforestation. }\end{array}$ & 3 & 1.13 & -2 & $-0.78^{*}$ & 2 & 0.79 \\
\hline 16 & $\begin{array}{l}\text { The big producers are overprotected concerning } \\
\text { land rights. }\end{array}$ & 1 & 0.77 & -2 & -0.79 * & 0 & 0.30 \\
\hline 33 & Lack of education causes people to cut trees. & -1 & -0.32 & -3 & -0.83 & 1 & 0.44 \\
\hline 17 & $\begin{array}{l}\text { When they cut trees, it's like they cut my mother } \\
\text { because they provide me with food and shade. }\end{array}$ & 1 & 0.77 & -3 & $-1.08 *$ & 3 & 1.26 \\
\hline 30 & $\begin{array}{l}\text { The national government gets all the benefits } \\
\text { of deforestation. }\end{array}$ & 1 & 0.54 & -3 & $-1.28 *$ & 0 & 0.04 \\
\hline 36 & $\begin{array}{l}\text { We are dying because of the pesticides that they put } \\
\text { on the fields. }\end{array}$ & 0 & -0.01 & -4 & $-1.88^{*}$ & 1 & 0.59 \\
\hline 31 & Social inequality causes deforestation. & -1 & -0.24 & -5 & $-2.01 *$ & 0 & 0.16 \\
\hline
\end{tabular}


Table A3. Distinguishing Statements for Factor 3.

\begin{tabular}{|c|c|c|c|c|c|c|c|}
\hline \multirow[b]{2}{*}{ No. } & \multirow{2}{*}{$\begin{array}{l}\text { Distinguishing Statements for Factor } 3(p<0.05 \\
\left.\text { Asterisk }\left(^{*}\right) \text { Indicates Significance at } p<0.01\right) \\
\text { Statement }\end{array}$} & \multicolumn{2}{|c|}{ Factor 1} & \multicolumn{2}{|c|}{ Factor 2} & \multicolumn{2}{|c|}{ Factor 3} \\
\hline & & Q-SV & Z-SCR & Q-SV & Z-SCR & Q-SV & Z-SCR \\
\hline 24 & $\begin{array}{l}\text { Everybody should respect the indigenous people's } \\
\text { right to land. }\end{array}$ & 0 & 0.23 & 3 & 1.21 & 5 & 1.90 \\
\hline 7 & $\begin{array}{l}\text { The indigenous peoples are excluded from } \\
\text { decisions about deforestation. }\end{array}$ & 0 & 0.33 & 0 & -0.07 & 4 & $1.43 *$ \\
\hline 8 & $\begin{array}{l}\text { It is unfair that the processes for deforestation } \\
\text { permissions are fast, while those for protection } \\
\text { are slow }\end{array}$ & 4 & 1.33 & 0 & -0.41 & 1 & 0.49 \\
\hline 33 & Lack of education causes people to cut trees. & -1 & -0.32 & -3 & -0.83 & 1 & 0.44 \\
\hline 23 & $\begin{array}{l}\text { If I own land, I should be allowed to use it the way I } \\
\text { want to. }\end{array}$ & -4 & -1.72 & -4 & -1.41 & 0 & $0.08 *$ \\
\hline 15 & $\begin{array}{l}\text { The indigenous people only live in the forest } \\
\text { because there is no alternative. }\end{array}$ & -2 & -0.84 & 2 & 0.65 & -1 & -0.09 \\
\hline 4 & $\begin{array}{l}\text { The criollos are excluded from decisions } \\
\text { about deforestation. }\end{array}$ & 2 & 0.84 & 0 & 0.02 & -2 & $-1.12 *$ \\
\hline 13 & The forest is a resource that needs to be exploited. & -1 & -0.36 & 3 & 1.11 & -3 & $-1.42 *$ \\
\hline 20 & $\begin{array}{l}\text { The criollos produce in an environmentally } \\
\text { friendly way. }\end{array}$ & 3 & 1.21 & -1 & -0.67 & -3 & -1.47 \\
\hline 14 & $\begin{array}{l}\text { The indigenous people are overprotected } \\
\text { concerning land rights. }\end{array}$ & -2 & -0.81 & 1 & 0.41 & -4 & -1.55 \\
\hline
\end{tabular}

\section{References}

1. Temper, L.; Martinez-Alier, J. Environmental Justice Atlas. Available online: https://ejatlas.org/ (accessed on 9 September 2019).

2. Fehlenberg, V.; Baumann, M.; Gasparri, N.I.; Piquer-Rodriguez, M.; Gavier-Pizarro, G.; Kuemmerle, T. The role of soybean production as an underlying driver of deforestation in the South American Chaco. Glob. Environ. Chang. 2017, 45, 24-34. [CrossRef]

3. Monitoreo Desmonte. Monitoreo Socio-Ambiental de los Bosques Chaqueños. Available online: http: //lart.agro.uba.ar/monitoreo-de-desmonte/ (accessed on 12 March 2019).

4. Vallejos, M.; Volante, J.N.; Mosciaro, M.J.; Vale, L.M.; Bustamante, M.L.; Paruelo, J.M. Transformation dynamics of the natural cover in the Dry Chaco ecoregion: A plot level geo-database from 1976 to 2012. J. Arid Environ. 2015, 123, 3-11. [CrossRef]

5. Lapegna, P. The Expansion of Transgenic Soybeans and the Killing of Indigenous Peasants in Argentina. Soc. Without Bord. 2013, 8, 291-308.

6. Procasur-International Land Coalition- FIDA. Titularización de Tierras y su Impacto en Los Jóvenes Campesinos. Dos Estudios de caso en el Chaco argentino. Available online: http://www.landcoalition.org/ sites/default/files/documents/resources/argentina_v8.pdf (accessed on 10 October 2016).

7. Schmidt, M. "Ordenadores y ordenados": Actores en disputa en el ordenamiento territorial de bosques nativos en la provincia de Salta. Cuad. De Antropol. 2014, 11, 37-55.

8. Van Dam, C. Tierra, territorio y Derechos de Los Pueblos: Indígenas, Campesinos y Pequeños Productores de Salta. 2007. Available online: https://s3.amazonaws.com/academia.edu.documents/36974845/ PROINDER.pdf?AWSAccessKeyId=AKIAIWOWYYGZ2Y53UL3A\&Expires $=1551704897 \&$ Signature $=$ j5OBMYMhw5cYLXensuow1TygX3s\%3D\&response-content-disposition=inline\%3B\%20filename\%3DLa_ lucha_por_la_defensa_de_la_identidad.pdf (accessed on 4 March 2019).

9. Nolte, C.; Gobbi, B.; Le Polain de Waroux, Y.; Piquer-Rodríguez, M.; Butsic, V.; Lambin, E.F. Challenges in Attributing Avoided Deforestation to Policies and Actors: Lessons From Provincial Forest Zoning in the Argentine Dry Chaco. Ecol. Econ. 2018, 150, 346-352. [CrossRef] 
10. Ceddia, M.G.; Zepharovich, E. Jevons paradox and the loss of natural habitat in the Argentinean Chaco: The impact of the indigenous communities' land titling and the Forest Law in the province of Salta. Land Use Policy 2017, 69, 608-617. [CrossRef]

11. Fernández Milmanda, B.; Garay, C. Subnational variation in forest protection in the Argentine Chaco. World Dev. 2019, 118, 79-90. [CrossRef]

12. Aguiar, S.; Mastrangelo, M.E.; García Collazo, M.A.; Camba Sans, G.H.; Mosso, C.E.; Ciuffoli, L.; Schmidt, M.; Vallejos, M.; Langbehn, L.; Brassiolo, M.; et al. ¿Cuál es la situación de la Ley de Bosques en la Región Chaqueña a diez años de su sanción? Revisar su pasado para discutir su futuro. Ecol. Austral. 2018, 28, 400-417. [CrossRef]

13. REDAF. Actualizacion y Fortalecimiento del Plan de Ordenamiento Territorial de Las Areas Boscosas de la Provincia de Salta. Available online: http://redaf.org.ar/wp-content/uploads/downloads/2016/11/SECAMBIENTE-SALTA-RESUMEN-EJECUTIVO-REVISION-OTBN-2016-1.pdf (accessed on 18 September 2020).

14. Rodriguez-Piñeros, S.; Focht, W.; Lewis, D.K.; Montgomery, D. Incorporating Values into Community-Scale Sustainable Forest Management Plans: An Application of Q Methodology. Small-Scale For. 2012, 11, 167-183. [CrossRef]

15. Barry, J.; Proops, J. Seeking sustainability discourses with Q methodology. Ecol. Econ. 1999, 28, 337-345. [CrossRef]

16. Durning, D. Using Q-methodology to Resolve Conflicts and Find Solutions to Contentious Policy Issues. In The Role of Public Administration in Building a Harmonious Society: Selected Proceedings from the Annual Conference of the Network of Asia-Pacific Schools and Institutes of Public Administration and Governance (NAPSIPAG); Ahmad, R., Ed.; ADB: Mandaluyong, Manila, Philippines, 2006; ISBN 971561616X.

17. Milcua, A.I.; Sherrenb, K.; Hanspacha, J.; Absonc, D.; Fischer, J. Navigating conflicting landscape aspirations: Application of aphoto-based Q-method in Transylvania (Central Romania). Land Use Policy 2014, 41, 408-422. [CrossRef]

18. Martin, A. Just Conservation. Biodiversity, Well-Being and Sustainability; Routledge: London, UK, 2017; ISBN 9781315765341.

19. Bucher, E.H.; Huszar, P.C. Sustainable management of the Gran Chaco of South America: Ecological promise and economic constraints. J. Environ. Manag. 1999, 57, 99-108. [CrossRef]

20. Lambin, E.F.; Gibbs, H.K.; Ferreira, L.; Grau, R.; Mayaux, P.; Meyfroidt, P.; Morton, D.C.; Rudel, T.K.; Gasparri, I.; Munger, J. Estimating the world's potentially available cropland using a bottom-up approach. Glob. Environ. Chang. 2013, 23, 892-901. [CrossRef]

21. Basualdo, M.; Huykman, N.; Volante, J.N.; Paruelo, J.M.; Piñeiro, G. Lost forever? Ecosystem functional changes occurring after agricultural abandonment and forest recovery in the semiarid Chaco forests. Sci. Total Environ. 2019, 650, 1537-1546. [CrossRef]

22. Giménez, R.; Mercau, J.L.; Houspanossian, J.; Jobbágy, E.G. Balancing agricultural and hydrologic risk in farming systems of the Chaco plains. J. Arid Environ. 2015, 123, 81-92. [CrossRef]

23. Piquer-Rodríguez, M.; Torella, S.; Gavier-Pizarro, G.; Volante, J.; Somma, D.; Ginzburg, R.; Kuemmerle, T. Effects of past and future land conversions on forest connectivity in the Argentine Chaco. Landsc. Ecol. 2015, 30, 817-833. [CrossRef]

24. Baumann, M.; Gasparri, I.; Piquer-Rodríguez, M.; Gavier Pizarro, G.; Griffiths, P.; Hostert, P.; Kuemmerle, T. Carbon emissions from agricultural expansion and intensification in the Chaco. Glob. Chang. Biol. 2017, 23, 1902-1916. [CrossRef]

25. Sacchi, L.V.; Powell, P.A.; Gasparri, N.I.; Grau, R. Air quality loss in urban centers of the Argentinean Dry Chaco: Wind and dust control as two scientifically neglected ecosystem services. Ecosyst. Serv. 2017, 24, 234-240. [CrossRef]

26. Salta Government. Censos. Available online: http://estadisticas.salta.gov.ar/web/level3/2/1/110/101/null (accessed on 18 September 2020).

27. Buliubasich, E.C.; Gonzales, A.; Los Pueblos Indigenas de la Provincia de Salta. La Posesion y el Dominio de Sus Tierras. Departamento San Martin. 2009. Available online: http://www.opsur.org.ar/blog/wp-content/ uploads/2012/04/59090637-InformeDDHH-Indigenas-Salta.pdf (accessed on 20 February 2017).

28. Anaya, J. Report of the Special Rapporteur on the Rights of Indigenous Peoples: The Situation of Indigenous Peoples in Argentina. Available online: http://www.unsr.jamesanaya.org/docs/countries/2012-reportargentina-a-hrc-21-47-add2_en.pdf (accessed on 18 September 2020). 
29. Palmer, J.H. La Buena Voluntad Wichí. Una Espiritualidad Indígena; Ruta 81: Formosa, Argentina, 2005; ISBN 9789872248901.

30. Buliubasich, C. La política indígena en Salta. Límites, contexto etnopolítico y luchas recientes. Runa 2013, 1, 59-71.

31. Frere, P. Diagnóstico Sobre la Población Objetivo de Las Políticas de Desarrollo Rural de la Provincia de Salta; Serie Consultorias: Salta, Argentina, 2004; Available online: http://redaf.org.ar/wp-content/uploads/2012/12/ Diagnostico_poblacion-objetivo-Salta_desarrollo-rural-Frere-2004.pdf.

32. Krapovickas, J.; Garay, A. Una aproximación descriptiva a la desigualdad socio-territorial en ámbitos rurales del Noroeste Argentino en la primera década del siglo XXI. Estud. Geogr. 2017, 78, 605. [CrossRef]

33. Camino, M.; Cortez, S.; Altrichter, M.; Matteucci, S.D. Relations with wildlife of Wichi and Criollo people of the Dry Chaco, a conservation perspective. Ethnobiol. Conserv. 2018. [CrossRef]

34. Brown, S.R. Q technique and method: Principles and procedures. In New Tools for Social Scientists: Advances and Applications in Research Methods; Berry, W.D., Lewis-Beck, M.S., Eds.; Sage: Beverly Hills, CA, USA, 1986; pp. 57-76.

35. Watts, S.; Stenner, P. Doing Q Methodological Research: Theory, Method and Interpretation; Sage: London, UK, 2012.

36. Social Discourse and Environmental Policy. An Application of Q Methodology; Addams, H., Proops, J.L.R., Eds.; Edward Elgar Pub: Cheltenham, UK, 2001; ISBN 9781840642032.

37. Brown, S.R. A Match Made in Heaven: A Marginalized Methodology for Studying the Marginalized. Qual. Quant. 2006, 40, 361-382. [CrossRef]

38. Capdevila, R.; Lazard, L. “Is it just me... ?" Q methodology and representing the marginal. Operant Subj. 2008, 32, 70-84.

39. Zabala, A.; Sandbrook, C.; Mukherjee, N. When and how to use $Q$ methodology to understand perspectives in conservation research. Conserv. Biol. 2018, 32, 1185-1194. [CrossRef]

40. Armatas, C.; Venn, T.; Watson, A. Understanding social—ecological vulnerability with Q-methodology: A case study of water-based ecosystem services in Wyoming, USA. Sustain. Sci. 2016, 12, 105-121. [CrossRef]

41. Bredin, Y.K.; Linnell, J.D.C.; Silveira, L.; Tôrres, N.M.; Jácomo, A.A.; Swenson, J.E. Institutional stakeholders' views on jaguar conservation issues in central Brazil. Glob. Ecol. Conserv. 2015, 3, 814-823. [CrossRef]

42. Piquer-Rodríguez, M.; Butsic, V.; Gärtner, P.; Macchi, L.; Baumann, M.; Gavier Pizarro, G.; Volante, J.N.; Gasparri, I.N.; Kuemmerle, T. Drivers of agricultural land-use change in the Argentine Pampas and Chaco regions. Appl. Geogr. 2018, 91, 111-122. [CrossRef]

43. Steelman, T.A.; Maguire, L.A. Understanding participant perspectives: Q-methodology in national forest management. J. Pol. Anal. Manag. 1999, 18, 361-388. [CrossRef]

44. Zabala, A. Motivations and Incentives for Pro-Environmental Behaviour: The Case of Silvopasture Adoption in the Tropical Forest Frontier. Ph.D. Thesis, Dissertation, University of Camebridge, Camebridge, UK, 2015.

45. Nijnik, M.; Nijnik, A.; Bergsma, E.; Matthews, R. Heterogeneity of experts' opinion regarding opportunities and challenges of tackling deforestation in the tropics: A Q methodology application. Mitig Adapt. Strat. Glob. Chang. 2014, 19, 621-640. [CrossRef]

46. Rosenhead, J.; Mingers, J. Rational Analysis for a Problematic World Revisited: Problem Structuring Methods for Complexity, Uncertainty and Conflict, 2nd ed.; Wiley: Chichester, UK, 2008; ISBN 9780471495239.

47. Webler, T.; Danielson, S.; Tuler, S. Using Q Method to Reveal Social Perspectives in Environmental Research. Available online: http://seri-us.org/sites/default/files/Qprimer.pdf (accessed on 6 April 2017).

48. Schmolck, P. The QMethod Page. Available online: http://schmolck.org/qmethod/ (accessed on 26 October 2018).

49. Kline, P. An Easy Guide to Factor Analysis; Routledge: London, UK, 1994; ISBN 0415094909.

50. Stephenson, W. Technique of Factor Analysis. Nature 1935, 136, 297. [CrossRef]

51. Lundberg, A. Teachers' beliefs about multilingualism: Findings from $\mathrm{Q}$ method research. Curr. Issues Lang. Plan. 2019, 20, 266-283. [CrossRef]

52. Cohen, J. Statistical Power Analysis for the Behavioral Sciences, 2nd ed.; Erlbaum: Hillsdale, MI, USA, 1987; ISBN 9780121790608.

53. Stephenson, W. A Note on Estimating Standard Error of Factor Scores in Q-Method. Operant Subj. 1978, 1, 29-37.

54. Baldi, G.; Houspanossian, J.; Murray, F.; Rosales, A. Cultivating the dry forests of South America: Diversity of land users and imprints on ecosystem functioning. J. Arid Environ. 2015, 123, 47-59. [CrossRef] 
55. Boffa, N. Configuraciones históricas en la lucha por el territorio en el pilcomayo salteño, Argentina. Historical configurations in the struggle for the territory in the Pilcomayo Salteño, Argentina. Trama Rev. De Cienc. Soc. Y Humanid. 2017, 6, 8-23.

56. Berndt, C.; Bernhold, C. Lateinamerikanischer Neostrukturalismus: Sojaboom und wirtschaftliche Konzentration in Argentinien. Z. Wirtschaftsgeogr. 2017, 62, 30-45. [CrossRef]

57. Cáceres, D.M. Accumulation by Dispossession and Socio-Environmental Conflicts Caused by the Expansion of Agribusiness in Argentina. J. Agrar. Chang. 2015, 15, 116-147. [CrossRef]

58. Sacchi, L.V.; Gasparri, N.I. Impacts of the deforestation driven by agribusiness on urban population and economic activity in the Dry Chaco of Argentina. J. Land Use Sci. 2016, 11, 523-537. [CrossRef]

59. Gabay, M.; Alam, M. Community forestry and its mitigation potential in the Anthropocene: The importance of land tenure governance and the threat of privatization. For. Policy Econ. 2017, 79, 26-35. [CrossRef]

60. Arévalo, C.; Paz, J. Migrantes y Nativos en la Provincia de Salta. 2016. Available online: https://www. aacademica.org/carla.arevalo/6.pdf (accessed on 18 September 2020).

61. Barkin, D.; Lemus, B. Local Solutions for Environmental Justice. In Environmental Governance in Latin America; Castro, F., de Hogenboom, B., Baud, M., Eds.; Palgrave Macmillan: London, UK, 2016; pp. 257-286. ISBN 978-1-137-57408-4.

62. Pascual, U.; Balvanera, P.; Díaz, S.; Pataki, G.; Roth, E.; Stenseke, M.; Watson, R.T.; Başak Dessane, E.; Islar, M.; Kelemen, E.; et al. Valuing nature's contributions to people: The IPBES approach. Curr. Opin. Environ. Sustain. 2017, 26-27, 7-16. [CrossRef]

63. Boffa, N. Situaciones de Concentración y Disgregación Socila Wichí. La Lucha Permanente. Available online: https://www.researchgate.net/publication/306120245 (accessed on 18 September 2020).

64. Stevens, C.; Winterbottom, R.; Springer, J.; Reytar, K. Securing Rights, Combating Climate Change. How Strengthening Community Forest Rights Mitigates Climate Change. 2014. Available online: https: //www.wri.org/sites/default/files/securingrights-full-report-english.pdf (accessed on 18 September 2020).

65. Ceddia, M.G.; Gunter, U.; Corriveau-Bourque, A. Land tenure and agricultural expansion in Latin America: The role of indigenous peoples'and local communities' forests rights. Glob. Environ. Chang. 2015, 35, 316-322. [CrossRef]

66. Ceddia, M.G.; Gunter, U.; Pazienza, P. Indigenous peoples' land rights and agricultural expansion in Latin America: A dynamic panel data approach. For. Policy Econ. 2019, 109, 102001. [CrossRef] 